\title{
The Transmutation of Silver into Gold
}

\author{
THE LATE 19TH-CENTURY CLAIMS OF STEPHEN H. EMMENS
}

\section{George B. Kauffman}

Department of Chemistry, California State University, Fresno, California, U.S.A.

\begin{abstract}
Throughout the ages, man bas been intrigued by the idea of transmuting base metals into the 'king of metals'. Stephen H. Emmens, a late 19th-century scientist and entrepreneur, living and working in America, claimed to have transmuted silver into gold by bis so-called Argentaurum process. His work in this area and his exchange of correspondence with the eminent scientist Sir William Crookes make fascinating additions to the recent bistory of transmutation.
\end{abstract}

Because gold is found in relatively pure form in the native state, is beautiful, lustrous and workable and does not corrode or tarnish, it was one of the first metals known to man. It is therefore not surprising that it is the first element to be discussed in Weeks' 'Discovery of the Elements' (1). Gold ornaments have been found in Egyptian tombs of the stone age, and further evidence of the early knowledge of this precious metal can be found in Genesis, 2:11 and 12, which mentions the good gold of Havilah. Furthermore, Genesis, 4:22, describes Tubal-cain, a seventh-generation descendant of Adam and Eve, as 'an instructor of every artificer in brass and iron' Since the metallurgy of iron is considerably more complicated than that of gold, it is reasonable to conclude that a knowledge of gold and gold-working is virtually contemporaneous with the biblical origins of the human race.

Gold was one of the seven metals known to the ancients (gold, silver, iron, mercury, tin, copper and lead). These metals were associated with the seven heavenly bodies, the Anglo-Saxon names of which are familiar to us in the names of the days of the week (Table I). The relationship between the metals and these heavenly bodies was so intimate that the names and symbols of the planets were often used to refer to the metals $(2 a, 3)$. Since gold was the rarest and most prized of these metals, it was regarded as the most perfect. It is not surprising, therefore, that man developed fairly early in his history a protoscience known as alchemy, the main goal of which was to convert or transmute the base metals into gold, the 'king of metals'

\section{Alchemical Transmutations}

Alchemy has been called the daughter of error but the mother of truth. Although its premises were false, the practitioners of this venerable pseudo-science, in the course of their fruitless search, contributed much to modern chemistry and technology in the form of chemical substances, laboratory techniques and scientific apparatus (2). Transmutation, the key word characterizing alchemy, may be understood in a number of different ways. In the exoteric sense, the term refers to the conversion of base metals into gold, usually with the aid of a mysterious substance known as the philosopher's stone (4). This is the sense in which transmutation is understood by the general public and the sense in which it is used in this article. However, in the esoteric sense, transmutation can also refer to physiological changes, from sickness to health, from old age to youth, or even from an earthly to a supernatural existence. The search for the elixir of life and immortality was particularly associated with Eastern alchemy and the Taoist concept of the T'ai-chi, the first matter, which is divided into the two contraries Yin and Yang $(5,6)$. Some scholars, and particularly the Swiss psychiatrist Carl Gustav Jung, believed that alchemical transmutation referred to the

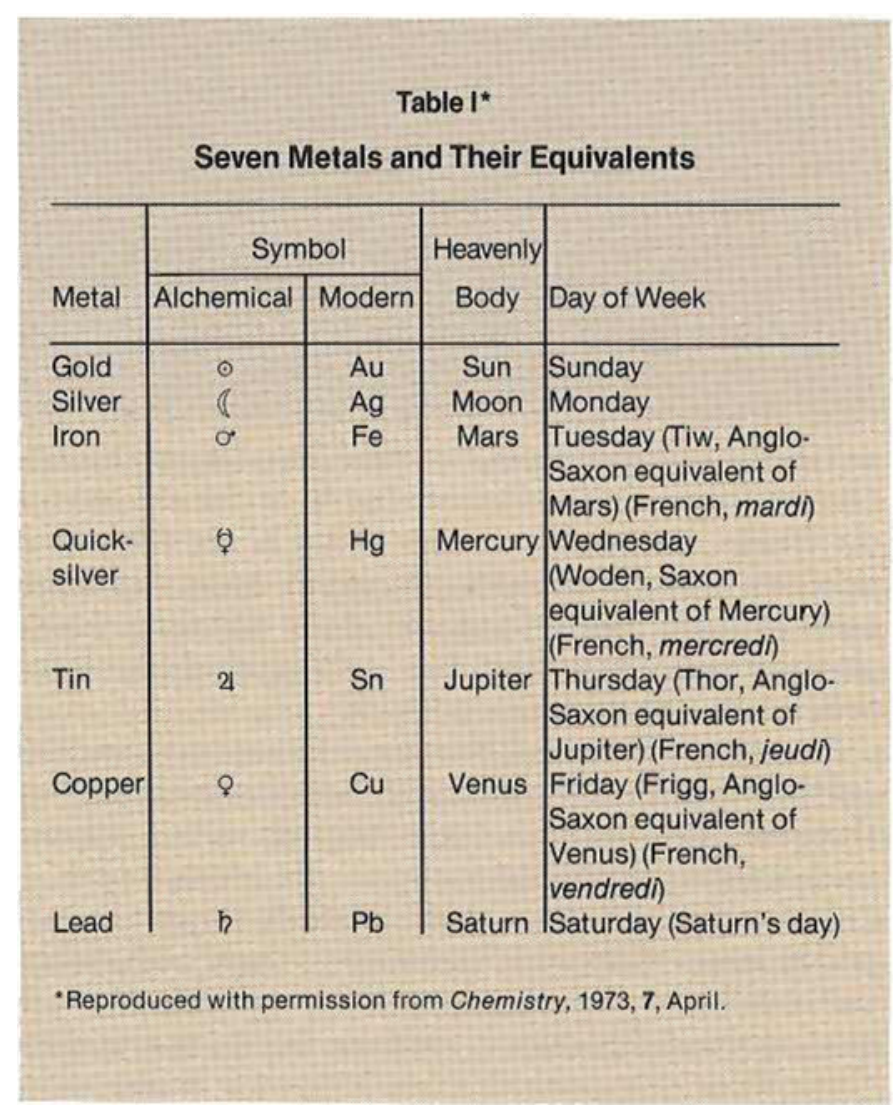




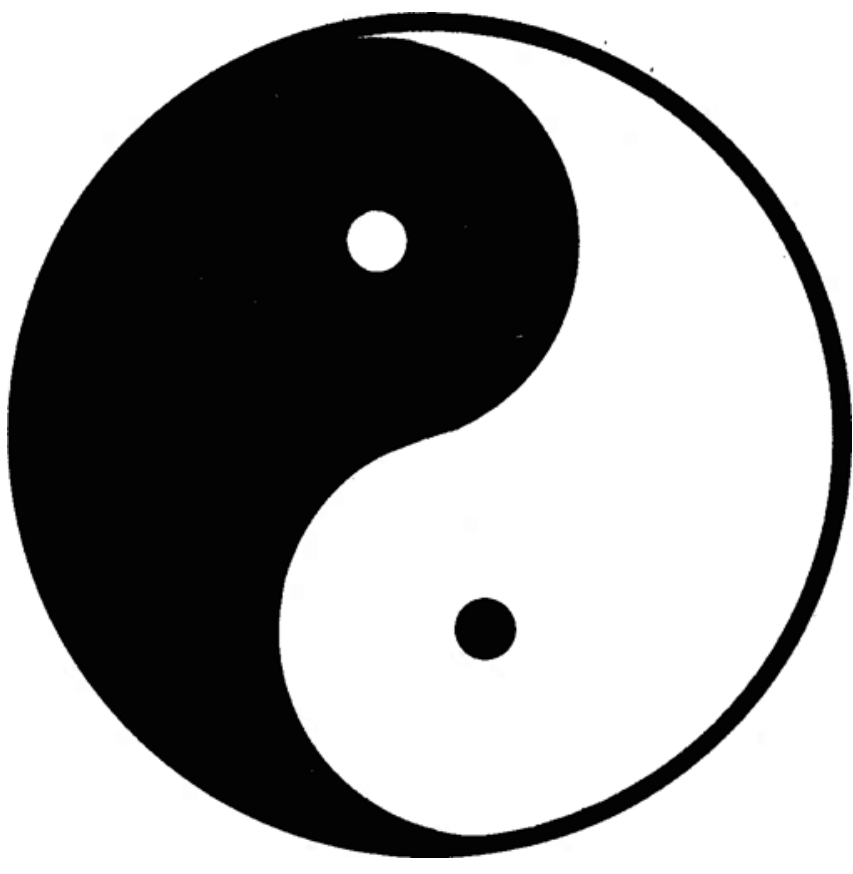

The two Contraries, Yin (dark area) and Yang (light area), of the $T^{\prime} a i$-chirepresentative of ultimate unity. Yang, the perfect, is associated with gold and the Sun

psychospiritual integration of man's fragmented psyche and that man himself is the base metal lead that is to be refined and perfected by the process of psychotherapy $(7,8)$. Continual change is a fundamental characteristic of the natural world, and the idea of transmutation seems to be completely in accord with this.

The idea of transmutation had as its basis the unity of matter. If the bewildering diversity of material substances could be reduced to a few fundamental 'elements', surely the interconvertibility of matter was a distinct possibility. Thus the various theories of matter - the two contraries ( $Y$ in and $Y a n g$ ) and the five elements (water, fire, wood, metal and earth) of the Chinese Taoists, the four elements (earth, air, fire and water) of the Greeks, the sulphur-mercury theory of the 8th-century alchemist Geber (Jábir ibn Háyyán) and the Arabs, and the tria prima (sulphur, mercury and salt) of the 16th-century Swiss physician and alchemist Paracelsus - all furnished a theoretical basis for the idea of transmutation (9).

According to Plato, undifferentiated matter was created first and then impressed with particular, individualizing qualities. Therefore, the alchemist began his task with a material unidentifiable by particular qualities — the 'element earth' and attempted to impose upon it gradually the properties of gold by means of the other 'elements' - 'water' or fusibility, 'air' or brilliancy and the colour of 'fire' and resistance to it. Alchemy was closely allied to astrology, and the process of the 'Great Work' of transmutation was believed to involve twelve operations or steps, each represented by a different sign of the Zodiac - calcination (Aries), congelation (Taurus), fixation (Gemini), solution (Cancer), digestion (Leo), distillation (Virgo), sublimation (Libra), separation (Scorpio), ceration (Sagittarius), fermentation (Capricorn), multiplication (Aquarius) and projection (Pisces).

The alchemists made extensive use of analogies and correspondences. In their eyes, if a substance was the colour of gold, it was believed to be gold. Also, their lack of knowledge concerning the composition of common substances led them to view some ordinary chemical reactions as transmutations. For example, the familiar oxidation-reduction reaction that occurs when a strip of iron is placed in a solution of copper sulphate:

$$
\mathrm{Fe}+\mathrm{CuSO}_{4} \rightarrow \mathrm{Cu} \downarrow+\mathrm{FeSO}_{4}
$$

has been known since the time of the Roman author Pliny the Elder (A.D. 23?-79). Blue vittiol $\left(\mathrm{CuSO}_{4} .5 \mathrm{H}_{2} \mathrm{O}\right)$ was then known as a natural product, but since it was not known to contain copper or to be preparable from it, the reaction was assumed to be a transmutation of iron into copper. This interpretation was widely accepted until the late Renaissance. Its correct modern interpretation was first given by the 17 thcentury Belgian physician Joan Baptist van Helmont, who noted that when dissolved in acids, metals are not destroyed and can be recovered from solution ( $4 \mathrm{~b})$.

A mere listing of all alleged cases of transmutation would fill an entire volume. Hermes Trismegistos, the legendary father of the 'divine art' of alchemy, alone is credited with 36000 alchemical writings. Many accounts of transmutations through the ages, which are discussed in a number of books $(8,10$ to 13$)$, read like fairy tales or mystery stories, involving mysterious strangers who perform their miracles and then disappear. As a case in point, we may cite the Comte de Saint-Germain, an 18 th-century chemist, alchemist, physicist, violinist, harpsichordist, composer, painter, hypnotist, polyglot, author, diplomat and spy, who boasted of having chatted with the Queen of Sheba, Cleopatra and Richard the Lionheart, and of having witnessed Christ's first miracle at the wedding feast at Cana (14). Standing squarely in the tradition of this rogues' gallery of charlatans, pretenders and other self-styled goldmakers, but much closer to our own enlightened and sophisticated time, stands the enigmatic figure of Stephen Henry Emmens.

\section{Emmens' Life and Work}

Since Emmens is not listed in any of the standard or even the obscure biographical dictionaries, we must have recourse to his own scanty statements, which, considering his propensity for prevarication and outright dishonesty, should be accepted only with reservations. Born in either England or Ireland in 1844 or 
1845, he attended King's College, London, whete he was awarded prizes in chemistry and physics in 1862 and 1863, respectively. Although he styled himself 'Doctor', he never cited the source, date, or field of study for this degree. He claimed to have been a superintendent of various chemical works, mines, metallurgical establishments and other industrial concerns. Sometime around 1877, he suffered a crippling injury to his spine, and in full-length photographs he is always shown in a wheelchair. In the 1880 's, he emigrated to the United States where he headed several businesses (Emmens Chemical and Explosives Co., Emmens Metal Co. and the Argentaurum Laboratory), and he seems to have disappeared from sight at about the turn of the century. He was a member of scientific societies such as the American Chemical Society and the American Institute of Mining, Metallurgical and Petroleum Engineers, and he was President of the Research Society, which he founded.

Two traits of Emmens' somewhat paranoid personality emerge from a reading of his works. First, he exhibited an aggressive contentiousness that made him prone to challenge what we would today call representatives of 'establishment science', especially academicians. Often this took the form of pointing out some minor errors and from this attacking an entire theory. Secondly, rather than allowing his work to stand on its own merits, he cited testimonials from other scientists who allegedly agreed with him, but who frequently had never even read his work.

Emmens was the inventor of a high explosive named Emmensite. He was an authority on metallurgy, especially that of nickel, tin and zinc, and he claimed to have discovered three new nickel minerals, the existence of which was apparently not accepted. His interests were not limited to chemistry or even to science, for he wrote novels and poetry as well as books on logic, philosophy, punctuation, mining, politics and taxation.

One of Emmens' most ambitious, but bizarre, works is 'The Argentaurum Papers No. 1' (15), a book which, despite its title, does not deal with gold, silver or gold-making but is an attempt to disprove Newton's theory of gravitation and to set up a new theory in its place. In attempting to correct some of Newton's small, perfectly valid approximations in Proposition LXXI of Book I of the 'Principia', Emmens made gross errors and drew completely incorrect conclusions. He deduced that the earth must be hollow and that it cannot possibly rotate on its own axis. Not unexpectedly, Emmens' book was not taken seriously in scientific circles.

\section{Transmutation and 19th-Century Science}

Before judging Emmens too harshly for his excursion into what might be considered modern alchemy, we should temember the extent to which leading chemists of the 19th century (for example, Humphry Davy, James Finlay Weir

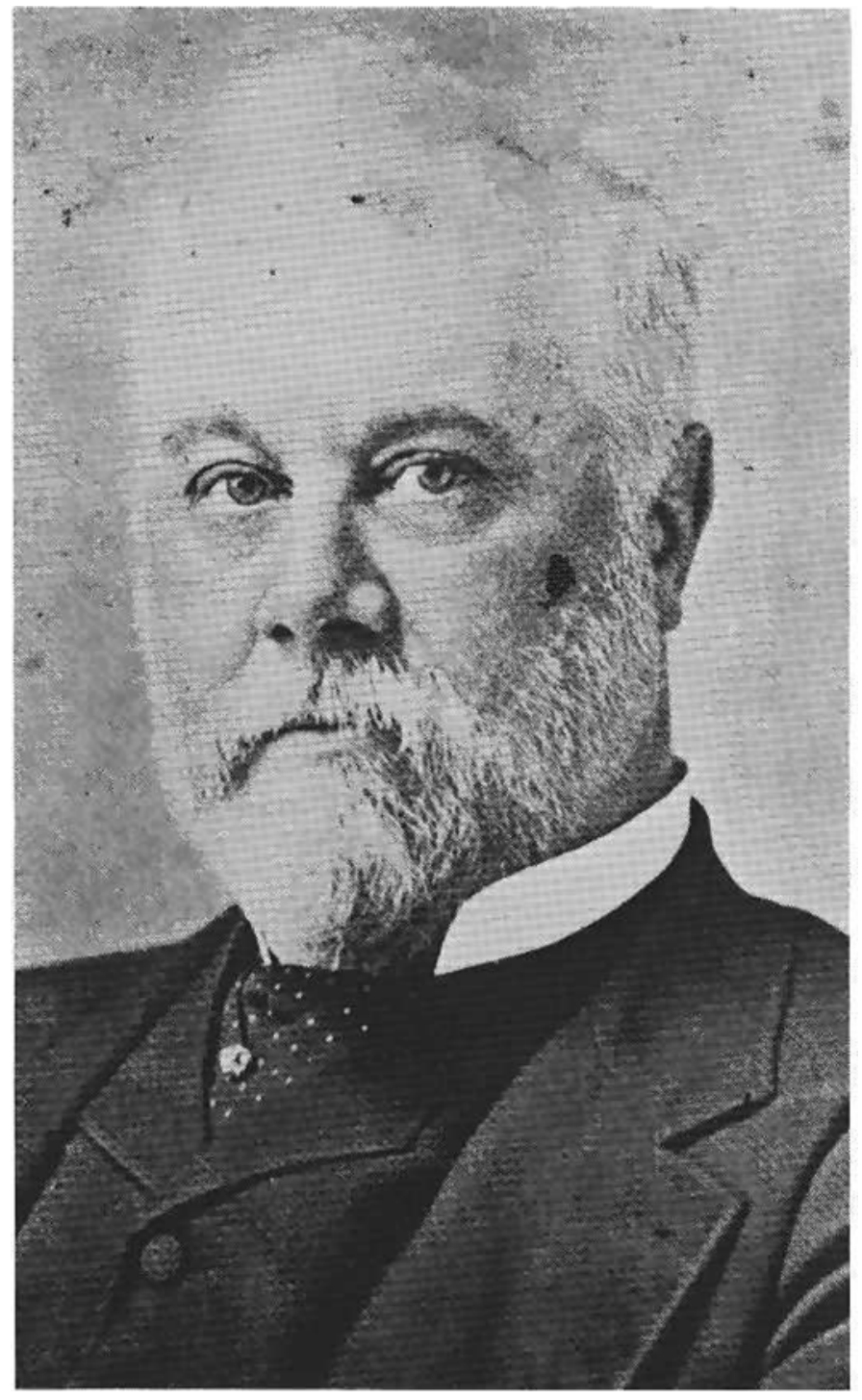

A portrait of Stephen H. Emmens, from the frontispiece of Argentaurana

Johnston, Justus Liebig, Jean-Baptiste Dumas, Hermann Kopp, Benjamin Brodie, Norman Lockyer, Thomas Sterry Hunt, Thomas Carnelley and William Crookes) expressed doubt not only as to the existence of atoms but also as to the elementary nature of the elements. In 1815, William Prout proposed his well-known hypothesis that the atomic weights of all elements are integral multiples of the atomic weight of hydrogen and that hydrogen might be the primary matter $(\pi \rho \omega \tau \eta \quad v \lambda \eta)$ of the ancients from which all the other elements were formed. Prout's fruitful idea stimulated interest not only in atomic weight determinations and atomic theory but also in the classification and 'evolution' of the elements and in atomic structure. 
The reasons for the renewed interest in alchemy prevalent during the fin de siècle were well summarized by the American chemist, bibliographer and historian of chemistry Henty Carrington Bolton, with whom Emmens exchanged polemics:

\begin{abstract}
'Recent discoveries in physics, chemistry, and psychology have given the disciples of Hermes renewed hopes, and the present position of chemical philosophy has given the fundamental doctrine of alchemy a substantial impetus. The favorite theory of a prima materia, or primary matter, the basis of all the elementary bodies, has received new support by the discoveries of allotropism of the elements, isomerism of organic compounds, the revelations of the spectroscope, the practical demonstrations by Norman Lockyer, the experiments on the specific heat of gaseous bodies at a high temperature by Mallard and Le Châtelier, the discoveries of Sir William Crookes (as set forth in his monograph on Meta-elements). the discovery by Carey Lea of several singular allotropic forms of silver, and, most weighty of all, the mass of related facts and phenomena which find their ultimate expression in the periodic law of the elements, so that many chemists of the present day are inclined to believe in the mutual convertibility of elements having similar chemical properties. '(16)
\end{abstract}

\section{Emmens' Argentaurum Process}

The first public disclosures by Emmens of his so-called Argentaurum process, on which he began work in 1892 , seem to have taken place during the summer of 1896, in several articles in New York newspapers where they elicited widespread interest (17). By using high pressure and intense cold, Emmens claimed to have converted silver into a substance intermediate between silver and gold, which exhibited 'the properties of ordinary metallic gold' and which he christened 'Argentaurum' :

'The metal which we have made from silver answers every test to which the United States Government Assay Office subjects the gold offered there for sale. It is, therefore, gold to all intents and purposes. This metal made from pure silver by the process discovered by us could be proved to be gold in a court of law. It not only answers every test of the Government mints, but it also has every quality required by the gold of commerce, having the same color, weight and strength'. (17c)

Although Emmens' claims were either attacked or met with considerable scepticism in articles published in scientific journals, such articles reached only a relatively small audience. His extravagant statements about such a sensational and controversial topic natutally furnished excellent copy for those journalists who were more credulous in their reporting. According to one such newspaper article, by early 1898 Emmens was 'producing enough gold to bring him at the [United States] assay office [in New York] a profit of $\$ 150$ a week', and Emmens confidently announced:

'I will take 1000000 ounces of silver, worth $\$ 500000$. . and from it I will make 600000 ounces of gold, worth $\$ 13$ an ounce. The cost of the gold will be $\$ 4600000$. Add to that the cost of the silver, $\$ 500000$, and subtract the whole from $\$ 7800000$, the value of the gold, and

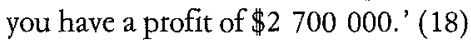

\section{Correspondence with Sir William Crookes}

Sir William Crookes, F.R.S. (1832-1919), chemist and physicist, Editor of Chemical News (1859-1919) " President of the Chemical Society (London) $(1886,1889)$, the British Association (1899), and the Royal Society (1913-1915), discoverer of thallium and of uranium- $X$, inventor of the radiometer and investigator of $\alpha$-rays, was one of the leading influential scientific authorities during the second half of the 19th century and the first two decades of the 20th century. Beginning in about 1870 , Crookes became interested in spiritualism and wrote a book on the subject. In 1897, the year in which he began his correspondence with Emmens, he was re-elected President of the Society of Psychical Research. He was therefore considered an open-minded authority on subjects that lay outside the pale of traditional science.

Although excerpts from the Emmens-Crookes correspondence appear in various articles, the entire correspondence (48 letters from 8th May, 1897 to 12 th May, 1898 consisting of 34 from Emmens and 14 from Crookes) comprises more than half (from page 70 to page 158) of Emmens' magnum opus 'Argentaurana', which also contains details of his Argentaurum process (19). According to Emmens:

'The scientific history of the argentaurum process is so bound up with Sir William's work and with the communications that have passed between him and myself that the simplest and best plan is to let out correspondence itself tell the story.'

The correspondence began with reciprocal goodwill and admiration but finally degenerated into mutual recriminations. Although, after the parting of their ways, Emmens still regarded Crookes as "the most illuminating scientific leader of the last quarter of a century' (20) and although he stated his intention 'to let our correspondence itself tell the story', he could not resist adding marginal comments that are slyly malicious and sarcastic.

Crookes initiated the correspondence on 8th May, 1897 requesting information on the Argentaurum process, and on 21 st May, 1897 Emmens replied in part:

'We now use Mexican silver dollars, and the operation consists of five stages, as follows:

(a) Mechanical treatment.

(b) Fluxing and granulation.

(c) Mechanical treatment.

(d) Treatment with oxides of nitrogen - i.e., a modified nitric acid.

(e) Refining.

When my force engine (now nearly finished) shall be ready, it will give us the means of readily producing pressures exceeding 500 tons per square inch. We look forward to accomplishing many marvels by its instrumentality. And I have every confidence that the production of Argentaurum gold will be brought up to 50000 ounces monthly within a year.'

On 7th June, 1897 with his characteristic lack of modesty, 
Emmens notified Crookes that:

'Out force engine is complete and ready for inspection. It will, I believe, prove to be the most important piece of laboratory apparatus ever produced.'

On 3rd July, 1897 Crookes replied:

'Your statements are most startling, and if there is no fallacy in your experiments, and I confess I do not see any, assuming they are carried out as you say, the discovery is one of the most important of the century.'

He also pressed Emmens for 'a few more details' about the process and the force engine, asked for 'a small piece of gold you have made' for spectrographic examination and assured Emmens that:

'I am regarding your communications as strictly private, and I hope you will consider mine to you on this subject the same.'

Since Emmens did not seem inclined to provide Crookes with specific details about the process, on 4th October, 1897 Crookes proposed.

'I think the best and simplest thing will be for me to come over to your factory and see the whole operation, and satisfy myself sufficiently on all points. ... If I were to be able to arrange to come would you let me see everything and let me examine and experiment with the machinery in my own way as I liked without restriction in any way?'

Emmens replied on 15th October, 1897 in his longest letter to date, that Ctookes' visit would be useless because the scientific world would not believe him, even if he had observed Emmens' successful process at first hand.

On 1st November, 1897 Crookes reported:

'I am disappointed that neither of the samples of argentaurum show any other lines than those due to gold, silver and copper. I am not able to detect a single new or unknown line. Perhaps if you were to send me some specimens in different stages of manufacture, one might detect something new.'

On 22nd February, 1898 in what Emmens later described as a 'historical letter', Crookes described at length some preliminary work to which Emmens later referred as 'your crucial experiment':

'I have now succeeded in getting a run of 40 hours with it, and on assaying the piece of Mexican dollar treated in it, and the rest of the Mexican dollat not treated, I find practically the same amount of gold in them. I am getting some defects remedied and intend to have another try. Perhaps, if I give you the particulars, you will tell me where I am wrong, and may make a suggestion which will improve the results.

I put about half an ounce of cuttings from a Mexican dollar into a steel mortar with a closely fitting piston, and screwed firmly on a strong base. Over the piston I have a steel bar 1.5 inches square, and sufficiently long enough to weigh 28 pounds. This was provided with a collar, and was raised and allowed to drop one foot by means of a cam on a rotating shaft. It made sixty blows a minute. The steel mortar was enclosed in a coil of pipes immersed in a water bath, and ice was put in the bath, and through the coil of pipe a slow current of liquid carbonic acid flowed. This kept the temperature down considerably below zero $F$. the whole of the time. The water was hard frozen the whole of the time of the operation. It went on for 40 hours, stoppage being allowed at night. (Say five days at eight hours a day.)

The results are as follows:

Hammered Mexican Silver taken for assay ................. 100.258 grains. Weight of gold bead ................................................. 0.075 grains.

Equal to ............................................................. 0.075 percent.

Some of the same silver before treatment ................ 96.837 grains.

Weight of gold bead ................................................. 0.060 grains.

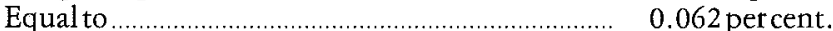

The difference is 0.013 per cent, which I consider is not enough to enable me to form an opinion on, as it is within the errors of experiment.'

In his next letter, dated 7th March, 1898, Emmens proposed his own interpretation of the 'crucial experiment', diametrically opposed to Crookes' view:

'I very heartily congratulate you on the success recorded in your letter of February 22nd. . .

You have obtained 75 parts of gold for every 62 parts you commenced with. This can't be explained away.

No admissible errors of observation can account for the increased yield of gold. The two beads weighed four and five milligrammes, 


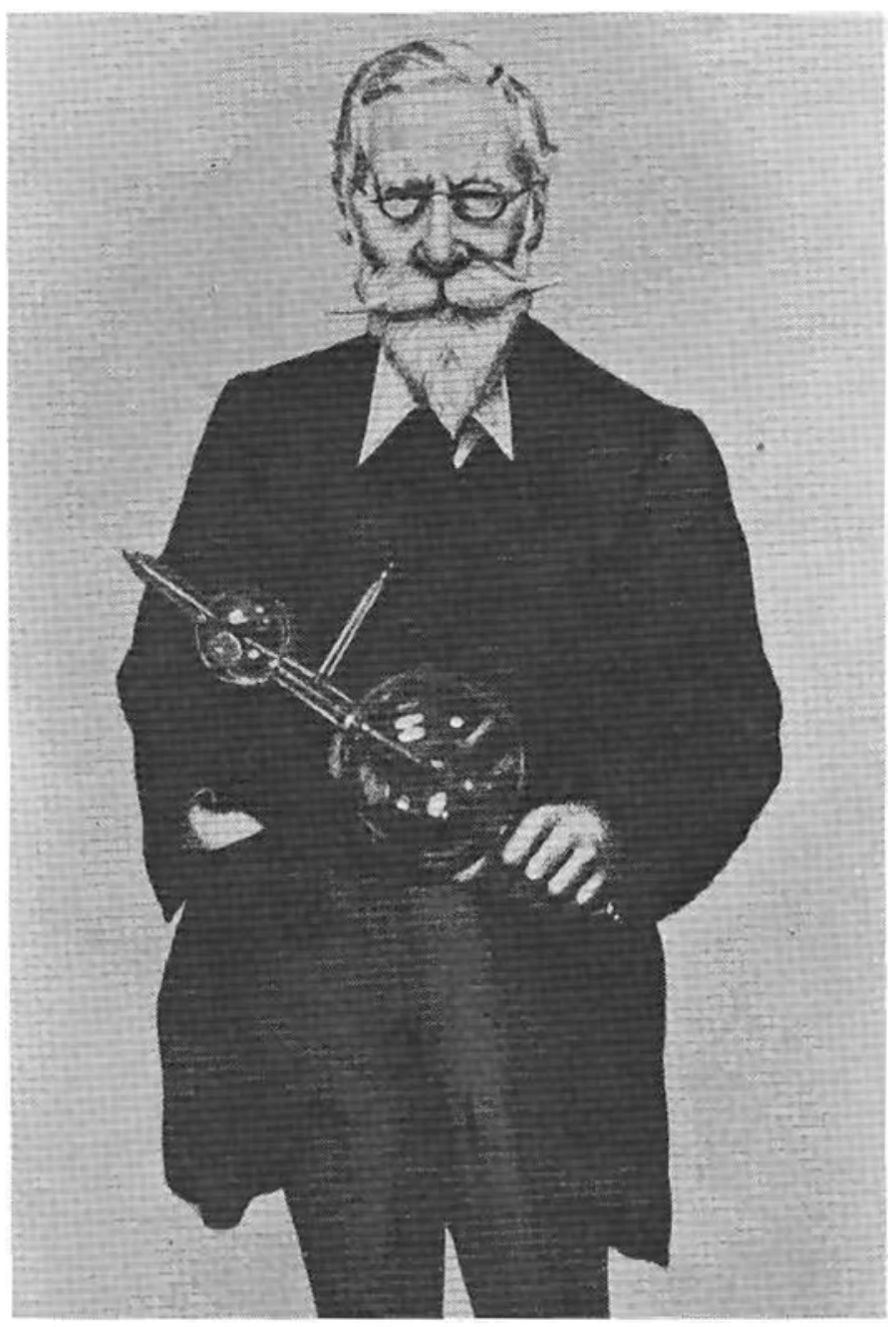

Sir William Crookes F.R.S. A caricature by 'Spy', Sir Leslie Ward entitled 'Ubi Crookes ibi lux' which appeated in Vanity Fair, 1903, 21st May

respectively. 'This, in the case of an assay of gold ore, would mean a difference of $\$ 20$ per ton; and every ordinarily competent assayer is expected to get results not varying more than 10 cents per ton. Such, at least, is the case in this country; and I think I am not assuming too much when I give Sir William Crookes, F.R.S. the credit of being able to determine gold just as closely as the average American chemist. At the same time your experiment was so incomplete from my point of view that I fecl quite surprised at its degree of success. I can account for this only by having regard to the long-continued duration of the impact treatment which much exceeded any thing I have done.'

On 19th March, 1898 Crookes wrote:

'I have just completed another experiment with all the accuracy and precaution I can think of. The discs of Mexican dollars I took were cut from two which contained no gold to begin with; and after hammering, as already described, for 97 hours. I assayed them, and have found absolutely no gold in either of them.
As my name has been so freely used in the newspapers of this country in connection with 'Argentaurum', I feel it will be my duty to communicate these results to the Press. I will, however, wait till there is time for me to hear what you have to say about the experiment.'

On 31st March, 1898 Emmens criticized Crookes' second experiment and found it 'defective in many essential particulars'. More specifically he added:

'You have made two expetiments. In one you employed metal from a normal Mexican dollar and obtained an increase of nearly 21 per cent in the contained gold. In the other you employed abnormal Mexican dollars, and obtained no gold. It seems to me that your duty is to dispassionately announce both experiments.'

On 23rd April, 1898 Crookes wrote:

'I may fairly complain of the use you are making of my letters to you. you take very high ground and affect to despise the opinions of scientific men.'

He then cited a number of Emmens' remarks in this vein and added:

'These, and other passages I might quote from your letters, are clear enough as to your attitude towards men of science... . But l am at a loss to reconcile this disdainful attitude with the eager way at which you snatch at every word that is said in your favour by men of the despised sect, and insist on giving to an unsuccessful experiment I was rash enough to describe to you in confidence, an importance it does not deserve and an interpretation absolutely against my explicit declaration. I expressly told you that the difference in gold before and after treatment was within the errors of experiment. There is no need for sarcastic remarks about my ability to perform an accurate assay. I know how the first experiment was done, and what experimental errors were (unavoidably) introduced, and I can only repeat emphatically that the probable errors of this first, tentative, experiment were greater than the trifling difference found. You have no right to take my figures without my qualification and convert an unimportant difference of about the hundredth of a grain into an increase of ' 20.9 per cent' in the quantity of gold.

In the longest letter of the entire correspondence, dated 5 th May, 1898, Emmens attempted to answer Crookes' objections point by point and again praised Crookes' first experiment and criticized his second experiment. In his attempts to placate Sir William and to cite authorities for the scientific validity of Crookes' first experiment, Emmens quoted at length from an article by Professor John Mackenzie, a member of the Spokane (Washington) Academy of Science, a Fellow of Emmens' own Research Society and an obvious admirer of Emmens (21). In this newspaper article, Mackenzie quoted extracts from Crookes' letter of 22nd February, 1898 describing the 'crucial experiment' and the results obtained as well as Emmens' interpretation of these results. This latest and most egregious breach of confidence was the straw that broke the camel's back. Crookes terminated the correspondence with his letter of 30th April, 1898: 
'I am surprised and annoyed to see that you have published in the Spokane Miner a letter of mine which I especially marked 'Private', and have used it to try to make the public believe that Ihave succeeded in transmuting silver into gold. When I last week wrote to you I was not aware of this gross breach of all the laws of courtesy and etiquette which govern correspondence between gentlemen all over the civilized world. After such an occurrence I cannot continue a correspondence with you.'

In his final letter of 12th May, 1898 Emmens first protested his innocence. He then attempted to rationalize the matter and attributed Sir William's anger to his own sensitivity about his position in the scientific world. Sir William never replied, and the correspondence that had begun so auspiciously ended on a bitter note. This was indeed unfortunate, for if Emmens, by his premature disclosures of Crookes' preliminary results, had not forced him to terminate their correspondence, the latter might have gone on to perform repeated analyses to establish the variability in the gold content of Mexican silver dollars and thus to determine the margin of error of the experiment. Crookes might also have perfected a sampling process to establish the homogeneity of the silver dollars, so that the actual sample and the control (untreated) sample would have been shown to be identical in initial gold content within the limits of error. He might then have carried out a number of 'transmutation' experiments and shown the results to be reproducible. This would have resulted in a definite conclusion about Emmens' Argentaurum process. Lacking these experimental desiderata, Crookes' two experiments are inconclusive and neither prove nor disprove Emmens' claims. Furthermore, if Emmens had disclosed to Crookes the critical details of his process, so that the production of gold from silver would have been so large as to be unquestionable, or if he had allowed Crookes to visit the Argentaurum Laboratory and observe the process for himself, a definite conclusion, one way or the other, might have been reached. However, Emmens seems to have studiously avoided exactly those obvious straightforward conditions that would have led to a definitive proof or disproof of his claims. He followed the same tactics in his dealings with the New York Herald, which constitute the last chapter in our story.

\section{The New York Herald Episode}

On Sunday, 26th February, 1899 the New York Herald (the newspaper founded by James Gordon Bennett, who had sent Henry M. Stanley to Africa to find Dr. David Livingstone) ran a feature story about Emmens' process for making gold from Mexican silver dollars and challenged him to exhibit his process to a committee of scientists and citizens under controlled conditions. The article included a detailed table of records obtained from the United States Assay Office on Wall Street in New York showing that from 13th April, 1897 to 12th August,
1898 the Office had bought from Emmens 37 ingots, weighing from 7.04 to $50.96 \mathrm{oz}$. after melting, with a gold fineness ranging from 305.5 to 997.5 and a silver fineness ranging from 0 to 612 , for prices ranging from $\$ 95.65$ to $\$ 817.53$. From the table it may be calculated that in this 17 -month period Emmens had sold $934.86 \mathrm{oz}$. (945.49 oz. before melting) of metal, containing $616.89 \mathrm{oz}$. of gold and $296.92 \mathrm{oz}$. of silver, for the sum of $\$ 11971.74$.

In a letter of 23rd February, 1899 published in the New York Herald of 5th March, 1899, Emmens stated the conditions under which he would demonstrate his process:

\begin{abstract}
'My laboratory is a suspected place. ... The only satisfactory test would be to duplicate my plant elsewhere. I do not believe this could be done under a minimum cost of $\$ 10000$.

If the Herald does not care to take up the national test I suggest, but merely wants a trade test, I am quite willing to have a committee examine my laboratory. But these gentlemen would probably do $\$ 15000$ worth of damage before they were ready to begin work. 'That I should, of course, expect to be paid for.'
\end{abstract}

The Herald, not surprisingly, withdrew its challenge, and, as far as the published record shows, this constituted the swan song of Emmens' Argentaurum process.

\section{Conclusion}

On the basis of the meagre information available, a definitive assessment of Stephen H. Emmens and his work is difficult, if not impossible. The only period for which detailed facts are available is between about 1888 and 1899 , and even then large gaps occur. From this fragmentary information the portrait of Emmens that emerges is one of an unconventional', flamboyant, iconoclastic scientific and pseudo-scientific entrepreneur of wide interests, but with dubious academic credentials and with more than a touch of paranoia and megalomania. Immensely talented and multi-faceted, but often erratic, this eccentric and colourful character harboured deep-seated grievances against a professional scientific establishment which he felt had denied him the recognition that he deserved. He succeeded in alienating most of the professional scientists with whom he had extensive contact. On a number of occasions he was found guilty of dishonesty, for example, in his unauthorized use of the names of prominent scientists in connection with his advertisement of 'The Argentaurum Papers No. 1' Therefore, his unsubstantiated claims, especially the more extravagant ones, should be taken with more than a pinch of salt. Trimble, with perhaps more compassion than Emmens deserves, tentatively attributes his 'bitter and argumentative nature' to 'a good mind warped by frustration at his handicap' (Emmens' paralysis caused by an accident) (22). With some justification, Trimble feels that perhaps we are unfair in generalizing about Emmens' character from the events of his later life, but unfortunately this is the period to which most of the facts about 
him known to interested scholars are limited.

With regard to his gold-making, Emmens exhibited one of the hallmarks of the typical confidence man-the tactic of diversion. First, he gained the confidence of his 'marks' by establishing beyond a shadow of a doubt that he had sold metal ingots accepted by the U.S. Assay Office as containing gold. Both Sir William Crookes and the New York Herald then asked to observe Emmens' Argentaurum process at first hand, Crookes even being willing to cross the Atlantic in winter specifically for this purpose. Instead of granting these reasonable requests which would have furnished the most direct and incontrovertible proof of his claims, Emmens set up a distracting smokescreen. He adduced reasons why the requests were unacceptable and instead proposed something entirely different. In the case of the Herald, he asked that the newspaper build him an entire laboratory at a cost of at least $\$ 10000$. In other words, Emmens made a counter-proposal to which no sensible person would agree. When this was rejected, he was able to rationalise to himself and others that it was the other party and not himself who would not agree to the test. Thus, he ensured that a true 'crucial experiment' to test his process would never be carried out, through no ostensible fault of his own. If Crookes had not terminated his association with Emmens because of Emmens' violation of privacy and his distortion of Crookes' experimental results, Emmens would probably have manipulated the siruation to obtain the same result. In one way or another, Crookes would have been forced to break off communications with him.

Did Emmens succeed in converting silver to gold? Only Emmens himself knew. If his process was a hoax, then he was extremely clever in arranging matters so that no unequivocal test of it could be made and at the same time so that he could blame others for the failure to carry out such a test. If, on the other hand, his process was actually successful, then he was foolish and self-defeating in the way that he prevented such a test from being made-and everything that we know about Emmens points to the fact that he was far from foolish.

If the process was a hoax, then from where did Emmens' gold orginate? One possibility is that Emmens served as a 'fence' for stolen jewellery. If this were the case, why would he draw attention to himself by his exaggerated claims? Until further evidence is forthcoming, the affair remains a mystery. In Rupert T. Gould's words:

'Still, crank or not, Emmens' feat of persuading the United States Mint to buy a considerable quantity of what he assured them was artificial gold has never, I think been duplicated. Nor can I form any theory of fraud, which would make such a proceeding either practical or necessary. As to the facts of the sale, there is no doubt.' (23)
It is unfortunate that Emmens did not live to see the transmutation of bismuth into gold at the Lawrence Berkeley Laboratory by use of the high-powered BEVALAC particle accelerator (24). Bismuth is related to lead, one of the favourite raw materials of gold-seeking alchemists. Although the transmutation was far from cost-effective (the amount of gold produced at a cost of $\$ 10000$ was worth less than one-billionth of one cent), the elusive dream of medieval alchemists had been realized.

\section{References}

1 M.E. Weeks, 'Discovery of the Elements', 7th edition, completely revised and new material added by H.M Leicester, Journal of Chemical Education, Easton, PA., 1968, pp. 6-13

2 (a) G.B. Kauffman and Z.A. Payne, Chemistry, 1973, 46, (4), 6-10; and The Hexagon, 1980, 70, (2), 35-38

(b) G.B. Kauffman and Z.A. Payne, Chemistry, 1973, 46, (11), 6-11; and The Hexagon, 1980, 70, (3), 67-72

3 J.R. Partington, Ambix, 1937, 1, 61-64

4 (a) A.T. Schwartz and G.B. Kauffman, J. Chem. Educ, 1976,53, 136-138 (b) A.T. Schwartz and G.B. Kauffman, J. Chem. Educ., 1976, 53, 235-239

5 J. Needham with I. Gwei-Djen, 'Science and Civilisation in China', Vol. 5 Part 2, Cambridge University Press, New York, 1974

6 G.B. Kauffman and R. Toll, The Hexagon, 1982, 73, (2), 35-38; and Rev. Chil. Ėuc. Quím., 1980, 5, (1), 7-14

7 C.G.Jung, 'Mysterium Coniunctionis: An Inquiry into the Separation and Synthesis of Psychic Opposites in Alchemy', 1963; 'Alchemical Studies', 1967; 'Psychology and Alchemy', 1968. These three books are all translated by R.F.C. Hull and published by Princeton University Press, Princeton, N.J.

8 'T. Burckhardt, 'Alchemy: Science of the Cosmos, Science of the Soul' translated by W. Stoddart, Vincent Stuatt and John M. Watkins, Somerset, 1971, Penguin Books, Baltimore, MD., 1971

9 G.B. Kauffman, R.D. Myers and J. Koob, Chemistry, 1976, 49, (9), 12-17 and The Hexagon, $1980,70,(4), 88-92$

10 K.K. Doberer, 'The Goldmakers: 10000 Years of Alchemy', Nicholson and Watson, London, 1948; Greenwood Press, Westport, CT., 1972

11 F.S. Taylor, 'The Alchemists: Founders of Modern Chemistry', Henry Schuman, New York, 1949

$12 \mathrm{~J}$. Read, 'Prelude to Chemistry: An Outline of Alchemy, Its Literature and Relationships', MIT Press, Cambridge, MA., 1966

13 R.P. Multhauf, 'The Origins of Chemistry', Oldbourne, London, 1966; Franklin Watts, New York, 1967

14 G.B. Kauffman and R.J. Broughten, The Hexagon, 1979, 70, (1), 20-22 and Rev. Chil. Educ. Quim., 1979, 4, (5), 230-233

15 S.H. Emmens, 'The Atgentaurum Papers, No. 1 Some Remarks Concerning Gravitation. Addressed to the Smithsonian Institution, the Académie des Sciences, the Royal Society and All Other Learned Bodies' Plain Citizen Publishing Co., New York, 1897. Most of the scanty blographical data on Emmens are found in the 'Envoy' of this work (pp. 130-149)

16 H C. Bolton, Science, 1897, 6, 853-863

H.C. Bolton, Chem. News, 1898, 77, 69-70 and 73-74

17 (a) New York Press, 8th August, 1896

(b) Evening Sun (New York), 10th August, 1896

(c) New York Joumal, 16th August, 1896

18 J.C. Ridpath, The Arena, 1898, 19, (January), 138-140

19 S.H. Emmens, 'Agentaurana or Some Contributions to the History of Science', Geo. Du Boistel \& Co., Bristol, 1899

20 See (19), p. 70

21 J. Mackenzic, The Spokane Miner and Electrician, 7th April, 1898, pp. 2-3

22 R.F. Trimble, The Hexagon, 1981, 71, (3), 41-44

23 R.T. Gould, 'Enigmas', Philip Allan and Co., London, 1929, p. 249; 2nd edition, Paperback Library, New York, 1969, p. 234

24 K. Aleklett, D.J Morrissey, G.T. Seaborg and W. Loveland, 'Production of Gold Isotopes by Relativistic Heavy Ion Reactions with Bismuth' paper presented before the Division of Nuclear Chemistry and Technology, 179 th National Meeting, American Chemical Society, Houston, TX., 1980, 24th March

K. Aleklett, D.J. Morrisscy, W. Loveland, P.L. McGaughey and G.T. Seaborg, Phys. Rev. C, 1981, 23, (3), 1044-1046 